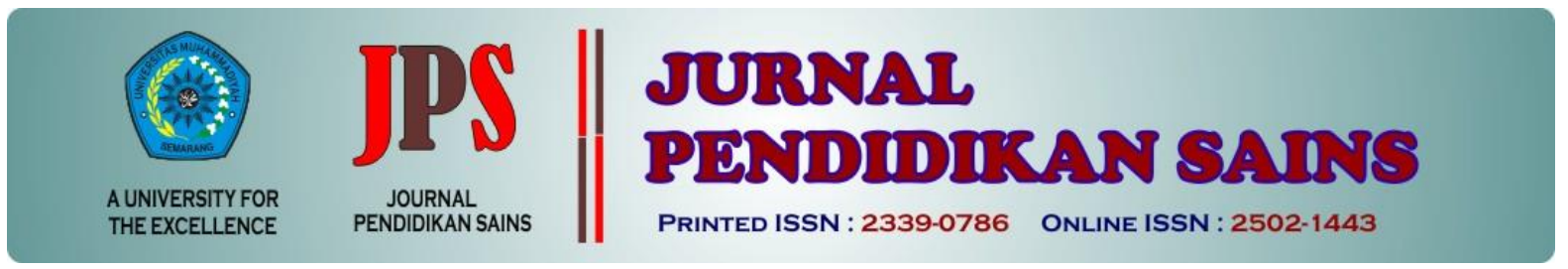

http://jurnal.unimus.ac.id/index.php/JPKIMIA

\title{
OPTIMALISASI PEMAHAMAN FISIKA PADA HUKUM NEWTON DENGAN INQUIRY - HEURISTIK VEE BERBANTUAN ALAT PERAGA
}

\author{
Oleh: Nurin Fitriana \\ Universitas Wisnuwardhana Malang
}

\begin{tabular}{|c|c|}
\hline Article History & Abstract \\
\hline sion: 2020-01-06 & \multirow{4}{*}{$\begin{array}{l}\text { This study aims to improve the optimization of students in the ability to } \\
\text { construct their knowledge in understanding the concepts of Basic } \\
\text { Physics in particular Newton's Law with Inquiry-Heuristic Assisted Vee } \\
\text { Aids. The type of research used in this study is the type of explanatory } \\
\text { research and analysis used in this study using SPSS, Descriptive } \\
\text { Interpretation, Pearson Correlation Interpretation, linear regression, } \\
\text { ANOVA. The results showed that the Pearson correlation test showed a } \\
\text { value of } 0.666 \text { shows a positive correlation between the ability of } \\
\text { knowledge construction with learning outcomes. Analysis of the } \\
\text { coefficient of determination is } 0.444 \text {, which means that the influence of } \\
\text { the ability of knowledge construction to learning outcomes is } 44.4 \% \\
\text { with F value }=18,339 \text {. The regression model can be used to predict the } \\
\text { participation variable. Thus it is stated that the ability of knowledge } \\
\text { construction has a strong degree of closeness to learning outcomes. }\end{array}$} \\
\hline Revised & \\
\hline :2020-05-05 & \\
\hline $\begin{array}{l}\text { Inquiry - Heuristic Vee, } \\
\text { knowledge construction }\end{array}$ & \\
\hline
\end{tabular}

\section{Pendahuluan}

Teknik Elektro merupakan salah satu program studi yang terdapat dalam Fakultas Teknik Universitas Wisnuwardhana Malang, yang mempunyai misi untuk menjadikan program studi ini unggul dalam menghasilkan sarjana teknik yang mandiri, profesional, kompetitif, dan berwawasan Ilmu Pengetahuan dan Teknologi. Program studi Teknik Elektro mahasiswa wajib mengikuti Matakuliah Fisika yang bertujuan untuk memberikan wawasan tentang konsep dasar Fisika dan penerapannya dalam kehidupan sehari-hari yang dapat bermanfaat dalam bidang Teknik atau sebaliknya.

Corresponding Author:

$\begin{array}{ll}\text { Nama } & \text { : Nurin Fitriana } \\ \text { Lembaga } & \text { : Universitas Wisnuwardhana Malang } \\ \text { Email } & \text { : nurin.unidha@gmail.com }\end{array}$

Keberhasilan pencapaian tujuan pendidikan dan pengajaran tidak lepas dari peranan dosen dan satuan pendidikan yang tegabung dalam Pendidikan tinggi. Paradigma peserta didik yang terlihat kurang aktif, cenderung mendengar atau mencatat yang disampaikan oleh pengajar sehingga pembelajaran hanya berjalan satu arah saja(Farida, 2015). Hal ini seharusnya sudah tidak terjadi pada Pendidikan di IndonesiaSalah satu upaya untuk meningkatkan kualitas belajar yaitu adanya suasana belajar yang dapat mengkonstruksi secara aktif pada mahasiswa. Dapat menggunakan pembelajaran inovatif yaitu pembelajaran inovatif pebelajarlah yang aktif dalam membangun dan membentuk pengetahuannya (Pradani, 2018)

Fisika adalah salah satu ilmu dalam bidang sains yang dipelajari melalui pendekatan matematis, sehingga seringkali ditakuti dan cenderung tidak disukai oleh 
sebagian besar peserta didik(Pramesty \& Prabowo, 2013). Fisika merupakan bagian ilmu pengetahuan alam yang mempunyai konsep-konsep dasar dalam ilmu Teknik. Oleh karena itu, fisika merupakan cabang ilmu pengetahuan yang sangat penting. Akan tetapi banyaknya materi yang terkait dengan konsep dan teori berhubungan dengan alam dan sulit diamati secara langsung, maka fisika merupakan mata kuliah yang dianggap sulit untuk dipelajari. Salah satu materi yang dianggap bersifat abstrak dan tidak dapat diamati secara langsung adalah materi hukum newton (Rosdianto et al., 2017). Penguasaan konsep siswa terkait konsep hukum newton masih rendah (Nuriyah et al., 2017).

Berdasarkan hal tersebut perlu dirancang model pembelajaran yang mempermudah kegiatan belajar. Pendidikan akan membantu mahasiswa dalam mengembangkan aspek kognitif, afektif, psikomotor. Oleh karena itu, penting bagi dosen untuk mengetahui kemampuan yang dimiliki peserta didik dan kesulitan-kesulitan mereka selama proses pembelajaran (Suhyanto $\&$ Musyrifah, 2016).

Model pembelajaran inquiry bertujuan untuk melatih kemampuan mahasiswa untuk melakukan penelitian, menjelaskan fenomena, menemukan inti, dan makna dari suatu masalah, dan memecahkan permasalahan melalui prosedur ilmiah yang dilakukan secara mandiri. Salah satu alternatif pembelajaran yang dapat diterapkan untuk meningkatkan kemampuan berpikir kritis siswa adalah pendekatan inquiry/discovery (Ahmatika, 2017). Hasil belajar yang menggunakan inquiry lebih baik daripada model konvensional (Setiawan, 2013). Terdapat perbedaan yang signifikan sikap ilmiah dan hasil belajar siswa antara kelompok model pembelajaran inkuiri terbimbing dan kelompok model pembelajaran konvensional (Dewi et al., 2013).

Penerapan pembelajaran inquiry dapat di lakukan dengan strategi Heuristic Vee membantu menemukan bahwa makna dari seluruh pengetahuan pada akhir barasal dari kejadian atau objek yang diamati. Pembelajaran Heuristik vee dapat meningkatkan kemampuan pemahaman konsep peserta didik menggunakan strategi (Rahmawati et al., 2018). Tidak ada hasil pengamatan dari kejadian atau objek yang menerangkan makna atau objek itu sendiri.
Makna tersebut harus dikonstruksi dan seseorang perlu mengetahui seluruh elemen Vee berinteraksi sehingga dapat mengkinstruksi makna baru (Sucipta et al., 2014).

Strategi pembelajaran Heuristik Vee memberikan kesempatan pada mahasiswa untuk terlibat langsung dalam suatu penemuan konsep, sehingga mahasiswa termotivasi untuk mencari kebenaran dari suatu konsep. Selain itu, model ini memberikan kebabasan kepada siswa dalam menyatakan gagasannya masingmasing selama proses pembelajaran,sehingga pembelajaran terkesan lebih santai dan bermakna. Beberapa penelitian menyebutkan bahwa model ini juga meningkatkan pemahaman konsep serta sikap ilmiah.(Hamzah, 2009)

Salah satu komponen dalam proses pembelajaran adalah sumber belajar, alat peraga merupakan salah satu dari sumber belajar. Penggunaan alat peraga dalam menerangkan ilmu yang abstrak dan sulit dapat membantu kelancaran proses pembelajaran (Setyowati et al., 2016). Alat peraga pembelajaran dapat berfungsi sebagai sarana dalam membantu dosen untuk menunjang komunikasi dengan mahasiswa. Penjelasan tersebut mengarah pada kesimpulan bahwa Model pembelajaran inquiry dipadu dengan strategi pembelajaran Heuristik Vee menggunakan alat peraga dapat memudahkan mahasiswa dalam memahami materi hukum grafitasi Newton yang pada umumnya sulit untuk dipahami. Pengukuran kemampuan dalam mengkonstruksi pengetahuan yang baik diharapkan dapat meningkatkan hasil belajar.

\section{Metode Penelitian}

Penelitian ini merupakan penelitian adalah tipe explanatory research. Penelitian kualitatif merupakan pendekatan penelitian yang mewakili paham naturalistik atau fenomenologis (Mulyadi, 2013). Output dari penelitian ini adalah produk yaitu berupa alat peraga sederhana berupa papan pengukur gaya hukum newton. Sampel penelitian sebanyak 25 mahasiswa adalah mahasiswa Program Studi Teknik Elektro Fakultas Teknik Universitas Wisnuwardhana Malang yang mengikuti perkuliahan Fisika.

Metode penelian kuantitatif adalah metode penelitian yang berlandaskan pada sifat positivisme, digunakan untuk meneliti pada populasi atau sampel tertentu yang memiliki 
tujuan menguji hipotesis yang telah ditetapkan dan digeneralisasikan. Tipe penelitian yang digunakan dalam penelitian ini adalah tipe explanatory research. Explanatory research. yaitu penelitian yang digunakan untuk menjelaskan hubungan kausal antara variabelvariabel melalui pengujian hipotesa yang dirumuskan atau sering kali disebut sebagai penelitian penjelas.

Waktu dan Tempat Penelitian. Penelitian ini dilaksanakan di Universitas Wisnuwardhana Malang pada masa perkuliahan semester genap tahun ajaran 2017/2018.

Teknik pengambilan sampel dalam penelitian ini menggunakan jenis non probability sampling yaitu dengan metode purposive sampling. Menurut Sugiyono purposive sampling adalah teknik penentuan sampel dengan pertimbangan tertentu (P.D, 2014)

Instrumen dan Teknik Pengumpulan Data Penelitian menggunakan teknik pengumpulan data berupa Angket dan kuesioner, yaitu cara pengumpulan data dengan menyebarkan suatu daftar yang berisi serangkaian pertanyaan tertulis. Kuesioner yang dibuat dengan kategori multiple choice dengan menggunakan skala likert, dimana setiap butir pertanyaan dibagi menjadi 5 skala ukur yaitu sangat setuju (skor 5), setuju (skor 4), netral (skor 3), tidak setuju (skor 4), sangat tidak setuju (skor 5). 2. Studi kepustakaan, dalam penelitian ini untuk mendapatkan data teoritis dari para ahli melalui sumber bacaan yang berhubungan dan menunjang terhadap penelitian ini baik dari buku, majalah, jurnal dan bacaan lainnya. Yang membantu penulis dalam menyusun, pengolahan hingga pembahasan data yang diperoleh. 3. Observasi lapangan, yaitu pengamatan dari peninjauan langsung terhadap objek yang diteliti.

Teknik Analisis Data. Analisis yang digunakan dalam penelitian ini menggunakan SPSS. SPSS merupakan salah satu software statistikyang biasa digunakan untuk pengolahan data(Sujarweni, 2014). Analisis persamaan regresi linear sederhana dilakukan untuk mengetahui besarnya pengaruh antara variabel bebas (kemampuan konstruksi pengetahuan) terhadap variabel terikat (hasil belajar). Setelah dilakukan analisis regresi maka akan diketahui apakah kedua variabel berpengaruh signifikan dan bagaimana pengaruhnya. Untuk mengukur seberapa besar dan bagaimana hubungan antara (kemampuan konstruksi pengetahuan) terhadap variabel terikat (hasil belajar) dengan metode korelasi Pearson.

\section{Hasil Penelitian dan Pembahasan}

Berdasarkan data penelitian yang telah dianalisa dengan hasil output program SPSS diperoleh sebagai berikut:

\section{A. Interpretasi Deskriptif}

Hasil statistik deskriptif menunjukan nilai ratarata dan standar deviasi baik kemampuan konstruksi pengetahuan maupun hasil belajar. Nilai standar deviasi yang lebih kecil dari nilai mean menunjukan kecenderungan data berdistribusi secara normal. Penelitian ini menggunakan 25 mahasiswa. Ditunjukkan pada tabel 1 .

Tabel 1. Data analisis statistik deskriptif

\section{Descriptive Statistics}

\begin{tabular}{ll|l|l|l|l} 
& $\mathrm{N}$ & Minimum & Maximum & Mean & Std. Deviation \\
\hline $\begin{array}{l}\text { Kemampuan } \\
\text { konstruksi } \\
\text { pengetahuan }\end{array}$ & 25 & 25.00 & 50.00 & 39.8000 & 5.99305 \\
\hline $\begin{array}{l}\text { Hasil belajar } \\
\begin{array}{l}\text { Valid } \\
\text { (listwise) }\end{array}\end{array}$ & N 25 & 12.00 & 25.00 & 19.4400 & 4.07308 \\
\hline
\end{tabular}

B. Interpretasi Korelasi Pearson

Hasil pearson correlation menunjukan nilai 0,666 , berdasarkan pedoman derajat hubungan menunjukkan bahwa terjadi korelasi kuat dengan probabilitas signifikansi 0,000 , sesuai dasar pengambilan keputusan bahwa signifikansi 
$<$ 0,05 (Creswell, 2012) sehingga disimpulkan adanya korelasi antara kemampuan konstruksi pengetahuan dengan hasil belajar. Kesimpulan : kemampuan konstruksi pengetahuan memiliki derajat keeratan yang kuat terhadap hasil belajar. Ditunjukkan pada tabel 2.

Tabel 2. Data analisis korelasi signifikansi

\section{Correlations}

\begin{tabular}{|c|c|c|c|c|}
\hline & & & $\begin{array}{l}\text { Kemampuan } \\
\text { konstruksi } \\
\text { pengetahuan }\end{array}$ & Hasil belajar \\
\hline \multirow{3}{*}{$\begin{array}{l}\text { Kemampuan } \\
\text { pengetahuan }\end{array}$} & \multirow[t]{3}{*}{ konstruksi } & Pearson Correlation & 1 & $.666^{* *}$ \\
\hline & & Sig. (2-tailed) & & .000 \\
\hline & & $\mathrm{N}$ & 25 & 25 \\
\hline \multirow{3}{*}{\multicolumn{2}{|c|}{ Hasil belajar }} & Pearson Correlation & $.666^{* *}$ & 1 \\
\hline & & Sig. (2-tailed) & .000 & \\
\hline & & $\mathrm{N}$ & 25 & 25 \\
\hline
\end{tabular}

**. Correlation is significant at the 0.01 level (2-tailed).

C. Analisis regresi linear sederhana

Tabel. 2 menunjukkan berapa besarnya nilai korelasi / hubungan (R) yaitu sebesar 0,666. Jika dihubungkan dengan pedoman tabel $r$, maka disimpulkan terdapat korelasi positif antara kemampuan konstruksi pengetahuan dengan hasil belajar. Dari output tersebut diperoleh koefisien determinasi ( $\mathrm{R}$ square) sebesar 0,444, yang mengandung arti bahwa pengaruh variable bebas (kemampuan konstruksi pengetahuan) terhadap variable terikat (hasil belajar) adalah sebesar $44,4 \%$.

Tabel 3. Data analisis regresi linear

\begin{tabular}{|c|c|c|c|c|c|}
\hline \multicolumn{6}{|c|}{ Model Summary } \\
\hline Model & $\mathrm{R}$ & R Square & $\begin{array}{l}\text { Adjustec } \\
\text { Square }\end{array}$ & $R$ & $\begin{array}{l}\text { Std. Error of } \\
\text { the Estimate }\end{array}$ \\
\hline$\overline{1}$ & $.666^{\mathrm{a}}$ & .444 & .419 & & 4.56642 \\
\hline
\end{tabular}

D. Analisis ANOVA

Dari output tersebut diketahui nilai $\mathrm{F}$ hitung= 18,339 dengan tingkat signifikansi sebesar $0,000<0,05$, maka model regresi

Tabel 4. Data analisis ANOVA dapat dipakai untuk memprediksi variable partisipasi atau dengan kata lain ada pengaruh variable kemampuan konstruksi pengetahuan $(\mathrm{x})$ terhadap hasil belajar $(\mathrm{y})$.

\begin{tabular}{|c|c|c|c|c|c|c|}
\hline ANOV & & & & & & \\
\hline Model & & $\begin{array}{l}\text { Sum } \\
\text { Squares }\end{array}$ & $\mathrm{df}$ & Mean Square & $\mathrm{F}$ & Sig. \\
\hline 1 & Regression & 382.399 & 1 & 382.399 & 18.339 & $.000^{\mathrm{b}}$ \\
\hline & Residual & 479.601 & 23 & 20.852 & & \\
\hline & Total & 862.000 & 24 & & & \\
\hline
\end{tabular}

a. Dependent Variable: Kemampuan konstruksi pengetahuan

b. Predictors: (Constant), Hasil belajar

Model Inquiry - Heuristik Vee merupakan model pembelajaran inquiry dengan menggunakan strategi Heuristik Vee. Model ini menggunakan langkah-langkah pembelajaran heuristik vee, yakni sebagai berikut:

1) Tahap orientasi 
Pada tahap ini pengetahuan awal mahasiswa yang terkait dengan topik pembelajaran akan digali oleh dosen. Dosen memusatkan perhatian mahasiswa dan menyebutkan permasalahan-pemasalahan fisika dalam kehidupan sehari-hari yang terkait dengan materi yang akan dipelajari.

2) Tahap pengungkapan gagasan mahasiswa

Pada tahap ini mahasiswa mengungkapkan gagasan masing-masing sesuai dengan pengetahuan awal yang dimiliki dan dosen tidak diperkenankan untuk membenarkan atau menyalahkan gagasan yang disampaikan mahasiswa.

3) Tahap pengungkapan permasalahan

Tahap ini dosen mengajukan permasalahan yang berkaitan dengan praktikum atau diskusi yang dilakukan dalam bentuk pertanyaan-pertanyaan kunci. Dosen dapat membagi kelas dalam beberapa kelompok dan memberiakan pertanyaan kunci atau permasalahan dalam bentuk lembar kerja.

4) Tahap pengkonstruksian pengetahuan baru

Mahasiswa melakukan praktikum atau diskusi dengan mengerjakan lembar kerja Bersama anggota kelompok dalam menyelesaikan permasalahan. Mahasiswa mengkonstruksi pengetahuan barunya dan membuat catatan penting atau kesimpulan yang kemudian dipresentasikan di depan kelas. Pada tahap ini dosen sebagai fasilitator dengan memberikan pertanyaan-pertanyaan kunci yang menuntun mahasiswa dalam menemukan pengetahuan baru.

5) Tahap evaluasi

Pada tahap ini dosen dan mahasiswa melakukan tanya jawab untuk menguatkan kembali gagasan mahasiswa. Dosen mencatat ide-ide pokok yang sesuai dengan konsep ilmiah di papan tulis dan mendiskusikan konsep mahasiswa yang salah, sehingga mahasiswa dapat mengetahui ketidaksesuaian gagasan yang dimiliki sebelumnya. Kemudian siswa membuat kesimpulan umum untuk menyelesaikan suatu permasalahan lain yang diberikan oleh dosen.

Model pembelajaran heuristic vee memiliki nilai psikologi sebab model pembelajaran heuristik vee tidak hanya mendorong belajar secara bermakna tetapi juga membantu mahasiswa memahami bagaimana proses menemukan pengetahuan. Gaya belajar adalah kunci utama untuk mengembangkan kemampuan berpikir peserta didik (Solikah \& Himmah, 2019). Mahasiswa diajarkan untuk memahami kejadian-kejadian alam yang dikaitkan dengan konsep-konsep fisika dan sikap ilmiah mahasiswa secara teori, sehingga pembelajaran lebih bermakna. Penerapan model pembelajaran heuristik veeakan memberian peluang bagi mahasiswa yang mempunyai kemampuan untuk mengemukakan gagasan-gagasan atau ide yang cemerlang, sehingga akan memberikan kesempatan kepada siswauntuk mencapai hasil yang optimal. Oleh sebab itu, mahasiswa sangat berperan aktif dalam proses pembelajaran, karena mahasiswa sendiri dalam berkelompok bias memecahkan masalah dan siswa bisa mengkaitkan antar konsep-konsep dengan kejadian-kejadian alam dengan menggunakan diagram vee. Digram vee dapat meningkatkan cara berfikir kritis (Hapsari et al., 2012). Pemahaman konsep dan sikap ilmiah mahasiswa sangat membangun pengetahuan awal mahasiswa tentang materi yang dipelajari.

Tabel 5. Perbedaan Strategi pembelajaran konvensional dengan pembelajaran Heuristik vee

\begin{tabular}{|c|c|c|c|}
\hline No. & Aspek & Heuristik Vee & Konvensional \\
\hline 1 & $\begin{array}{l}\text { Aktivitas } \\
\text { mahasiswa }\end{array}$ & $\begin{array}{l}\text { Mahasiswa dapat secara aktif } \\
\text { terlibat dalam kegiatan belajar, }\end{array}$ & $\begin{array}{l}\text { Mahasiswa tidak dituntut dalam } \\
\text { menemukan konsep sendiri }\end{array}$ \\
\hline 2 & Sumber belajar & Kerja kelompok dan diskusi & Pengajar \\
\hline 3 & Metode belajar & $\begin{array}{l}\text { Pemanfaatan diagram vee } \\
\text { kelompok dalam penyampaian } \\
\text { materi pembelajaran, }\end{array}$ & Met \\
\hline 4 & Kondisi kelas & $\begin{array}{l}\text { Mahasiswa dapat } \\
\text { mengkonstruksi pengetahuan } \\
\text { kedalam proses pembelajaran }\end{array}$ & $\begin{array}{l}\text { Mahasiswa belajar secara } \\
\text { individual dan pasif. }\end{array}$ \\
\hline 5 & Materi yang & Materi yang telah dipelajari & Rangkuman yang telah dipelajari \\
\hline
\end{tabular}


mahasiswa sangat membangun pengetahuan awal mahasiswa tentang materi yang dipelajari. Adapun saran yang dapat direkomendasikan adalah: (1) Bagi Dosen: Dosen yang akan memberikan materi tentang hukum newton dengan model diagram vee dapat mengarahkan mahasiswa untuk pengamatan alam secara langsung atau menggunakan kejadian alam; (2) Bagi mahasiswa: dalam membuat alat peraga dapat dicoba pula menggunakan beberapa massa atau penggerak, sehongga dapat lebih menyeluruh pembelajarannya.

\section{Daftar Pustaka}

Ahmatika, D. (2017). Peningkatan

Kemampuan Berpikir Kritis Siswa

Dengan Pendekatan Inquiry/Discovery.

Euclid.

https://doi.org/10.33603/e.v3i1.324

Creswell, J. W. (2012). Educational research:

Planning, conducting, and evaluating quantitative and qualitative research. In Educational Research. https://doi.org/10.1017/CBO9781107415 324.004

Dewi, N. L., Dantes, N., \& Sadia, I. W. (2013). Pengaruh Model Pembelajaran Inkuiri Terbimbing Terhadap Sikap Ilmiah dan Hasil Belajar IPA. Jurnal Program Pascasarjana Universitas Pendidikan Ganesha.

Farida, F. (2015). Pengaruh Strategi Pembelajaran Heuristic Vee Terhadap Kemampuan Pemahaman Konsep Dan Komunikasi Matematis Peserta Didik Kelas Viii Mts Guppiibabatan Lampung Selatan Tahun Pelajaran 2015/2016. AlJabar.

Hamzah. (2009). Teori Pembelajaran Kontruktivisme. Jurnal Psikologi Pendidikan.

Hapsari, D. P., Suciati Sudarisman, \& Marjono. (2012). Pengaruh Model Inkuiri Terbimbing Dengan Diagram V (Vee) Dalam Pembelajaran Biologi Terhadap Kemampuan Berpikir Kritis Dan Hasil Belajar Siswa. Pendidikan Biologi.

Ingram, J. (2014). Supporting student teachers in developing and applying professional knowledge with videoed events. European Journal of Teacher Education. https://doi.org/10.1080/02619768.2013.8 01074
Juwairiyah, J. (2013). Alat Peraga dan Media Pembelajaran Kimia. Visipena.

Mulyadi, M. (2013). Penelitian Kuantitatif Dan Kualitatif Serta Pemikiran Dasar Menggabungkannya. Jurnal Studi Komunikasi Dan Media. https://doi.org/10.31445/jskm.2011.1501 06

Nuriyah, R., Yuliati, L., \& Supriana, E. (2017). Konsep Hukum Newton. Pros. Seminar Pend. IPA Pascasarjana UM.

P.D, S. (2014). Metode penelitian pendidikan pendekatan kuantitatif.pdf. In Metode Penelitian Pendidikan Pendekatan Kuantitatif, Kualitatif Dan $R \& D$.

Pradani, N. M. N. (2018). PENGARUH Model Pembelajaran Heuristik Vee Berbantuan Media Video Terhadap Hasil Belajar Ipa Ditinjau Dari Motivasi Belajar. Jurnal Imiah Pendidikan Dan Pembelajaran. https://doi.org/10.23887/jipp.v2i2.15606

Pramesty, R., \& Prabowo, -. (2013). Pengembangan Alat Peraga Kit Fluida Statis Sebagai Media Pembelajaran Pada Sub Materi Fluida Statis Di Kelas Xi Ipa Sma Negeri 1 Mojosari, Mojokerto. Inovasi Pendidikan Fisika.

Rahmawati, R., Masykur, R., \& Fadila, A. (2018). Pengaruh Strategi Pembelajaran Heuristic Vee Terhadap Pemahaman Konsep Matematis Peserta Didik. Desimal: Jurnal Matematika. https://doi.org/10.24042/djm.v1i3.2620

Rosdianto, H., Murdani, E., \& Hendra. (2017). Implementasi Model Pembelajaran POE (Predict Observe Explain) untuk Meningkatkan Pemahaman Konsep Siswa pada Materi Hukum Newton. Jurnal Pendidikan Fisika.

SETIAWAN, D. (2013). Pengaruh Metode Pembelajaran Inkuiri Terhadap Ketuntasan Hasil Belajar Siswa Di Smkn 3 Buduran Sidoarjo. Jurnal Pendidikan Teknik Elektro.

Setyowati, N., Susilo, B. E., \& Masrukan. (2016). Penggunaan Alat Peraga untuk Meningkatkan Hasil Belajar dan Keaktifan Siswa pada Materi Peluang. Kreano.

Solikah, A., \& Himmah, W. I. (2019). Keefektifan Model Pembelajaran Means Ends Analysis Dengan Strategi Heuristik Terhadap Kemampuan Pemecahan Masalah Matematika. Hipotenusa : Journal of Mathematical Society. 
https://doi.org/10.18326/hipotenusa.v1i1. 3278

SUCIPTA, A., Suastra, M., \& Sadia, M. (2014). Pengaruh Model Pembelajaran Heuristik Vee Terhadap Pemahaman Konsep Fisika Dan Sikap Ilmiah Siswa SMA. Jurnal Pendidikan Dan Pembelajaran IPA Indonesia.

Suhyanto, O., \& Musyrifah, E. (2016). Pengaruh Strategi Heuristik Vee
Terhadap Kemampuan Pemahaman Konsep Matematik. FIBONACCI: Jurnal Pendidikan Matematika Dan Matematika. https://doi.org/10.24853/fbc.2.2.40-57 Sujarweni, V. W. (2014). SPSS untuk Penelitian. In SPSS untuk Penelitian. 